PRELIMINARY COMMUNICATIONS

\section{Blood Muramidase Activity in Colorectal Cancer}

\author{
E. H. COOPER, R. TURNER, L. STEELE, \\ J. C. GOLIGHER
}

British Medical fournal, 1974, 3, 662-664

\begin{abstract}
Summary
The serum muramidase levels were measured in 128 patients with primary or metastatic colorectal cancer, 166 tumour-free patients after resection of a colorectal cancer, and 172 controls. Muramidase levels over $10 \mu \mathrm{g} / \mathrm{ml}$ were detected in $30 \%-39 \%$ of the tumour-bearing patients, in $8.2 \%$ of the tumour free, and in only $1.7 \%$ of the controls (normal level $6.68 \pm 1.42 \mu \mathrm{g} / \mathrm{ml}$ ). Long-term follow up indicated that raised levels may occur as a transient phenomenon in recurrent or metastatic disease. The likely relation of abnormal serum muramidase activity and stimulation of the reticuloendothelial system is discussed.
\end{abstract}

\section{Introduction}

Muramidase (lysozyme); (EC 3.2.1.17) is a lysomal enzyme which is widely distributed in nature. Though in man this enzyme is found in most tissues the serum enzyme, under normal circumstances, originates from granulocyte and possibly monocyte turnover (Fink and Finch, 1968). Raised serum enzyme levels occur in renal failure (Prockop and Davidson, 1964; Hayslett et al., 1968), certain leukaemias (see review by Perillie and Finch, 1973), advanced sarcoidosis (Pascual et al. 1973), and tuberculosis (Perillie et al. 1973). Depression of the serum level has been reported in acute lymphocytic leukaemia (Rogoway and Finch, 1963) and agranulocytosis (Levi et al., 1973).

Fogelson and Lobstein (1954) first drew attention to increases in serum muramidase activity that may occur in cancer patients. These increases seemed to be independent of the site or extent of the tumour. Increased serum muramidase activity in the blood has been reported in bladder cancer (Kovanyi and Letnanski, 1971) and confirmed in our laboratory.

We report here the changes in serum muramidase that $\propto$ cured during the evolution of colorectal cancer. This work forms part of a broader study of chemical markers for diagnostic and prognostic purposes in this disease, and some of the results have been published elsewhere (Steele et al., 1974).

\section{Patients and Methods}

Patients attending the department of surgery of the General Infirmary at Leeds were the main subject of this study. Blood samples from some patients treated by two other surgeons

\footnotetext{
Department of Experimental Pathology and Cancer Research,

University of Leeds, Leeds LS2 9NL

E. H. COOPER, D.SC., F.R.C.P., Professor

R. TURNER, M.PHIL., Analyst

L. STEELE, M.A., Research Assistant

Department of Surgery, General Infirmary, Leeds

J. C. GOLIGHER, M.S., F.R.C.S., Professor
}

in the region were also examined. The series consisted of 60 patients before resection of a primary adenocarcinoma of the colon or rectum who were considered at laparotomy to have localized disease; 166 patients attending the follow-up clinic after resection of colorectal cancer and considered to be tumour free, being without clinical signs of tumour and biochemically within normal limits (serum $\gamma$-glutamyl transpeptidase $\leqslant 30 \mathrm{IU} / 1$, leucine aminopeptidase $\leqslant 60 \mathrm{IU} / 1$, and plasma carcinoembryonic antigen (C.E.A.) $\leqslant 25 \mathrm{ng} / \mathrm{ml}$ ); 39 patients with evidence of hepatic metastases, either observed at laparotomy or detected clinically or by scintillation scanning after a disease-free interval; and 29 patients with recurrence or local residual tumour spread in the pelvis. As preliminary studies had indicated that there could be transient increases in muramidase activity after major surgery no samples were included in this series within two months of the resection of the primary carcinoma.

Repeated observations over periods of three to 12 months were made on 60 of the postoperative patients-34 were judged to be tumour free throughout the period of study and 26 had clinical evidence of metastases, local recurrence, or biochemical changes and raised C.E.A. levels indicative of early metastases (Steele et al., 1974).

A total of 172 healthy blood donors were used to establish the normal range of enzyme levels and 11 patients with chronic renal failure were used as controls for the sensitivity of the assay. A further 53 patients with acute or chronic hepatitis and cirrhosis were studied to evaluate the effects of hepatic parenchymal cell disease on the blood muramidase activity. Assay of muramidase was based on the method of Kovanyi and Letnansky (1971). The assay was performed on a Pye-Unicam AC60 Chemical Processing Unit coupled to an AC62 Enzyme Programmer and a SP1800 spectrophotometer with an AR25 chart recorder. To $100 \mu$ l of serum was added $1.15 \mathrm{ml} 67-\mathrm{mM}$ phosphate buffer $\mathrm{pH} 6.2$ containing $0.1 \%$ sodium chloride. After equilibrium at $37^{\circ} \mathrm{C} 3.0 \mathrm{ml}$ of a suspension of $0.02 \%$ Micrococcus lysodeikticus was added in the above buffer. This was stirred and immediately transferred to a flow cell in the spectrophotometer where decrease in optical density at $37^{\circ} \mathrm{C}$ over a period of three minutes was recorded at $450 \mathrm{~nm}$. The amount of muramidase present was compared with a series of standards from $1 \mu \mathrm{g}$ to $25 \mu \mathrm{g} / \mathrm{ml}$ of hen egg white muramidase run on the same system.

C.E.A. was measured at the Chester Beatty Institute, London, by Professor A. Munro Neville's team using the Todd assay system (Egan et al., 1972).

\section{Results}

The number of observations made in each group of patients together with the mean \pm S.D.) and median are shown in the table. We arbitrarily set up a discriminant level of $10 \mu \mathrm{g} / \mathrm{ml}$ which is outside the $95 \%$ confidence limits of the normal range. The proportion of patients in each group whose values exceeded this level is shown in the table.

The preoperative muramidase values in patients with primary tumours without distant metastases were unrelated to the Dukes's grade or the tumour differentiation. After successful excision of the tumour the serum muramidase level of patients with preoperative increases returned to within normal limits (see fig.).

The serum muramidase was not correlated with the extent of metastatic involvement of the liver as judged by the size of the liver or the degree of abnormality of the liver function test results ( $\gamma$-glutamyl transpeptidase, leucine aminopeptidase, and alkaline phosphatase levels). 
Serum Muramidase Levels $(\mu \mathrm{g} / \mathrm{ml})$ in Seven Groups of Patients

\begin{tabular}{|c|c|c|c|c|c|c|c|}
\hline & Controls & $\begin{array}{c}\text { Postoperative } \\
\text { Tumour-free } \\
\text { Patients }\end{array}$ & $\begin{array}{l}\text { Patients with } \\
\text { Primary } \\
\text { Colorectal } \\
\text { Cancer* }\end{array}$ & $\begin{array}{l}\text { Patients with } \\
\text { Pelvic and } \\
\text { Metastases } \\
\text { Peritoneal }\end{array}$ & $\begin{array}{c}\text { Patients with } \\
\text { Hepatic } \\
\text { Metastases }\end{array}$ & $\begin{array}{c}\text { Patients with } \\
\text { Non-malignant } \\
\text { Liver Disease }\end{array}$ & $\begin{array}{l}\text { Patients with } \\
\text { Chronic } \\
\text { Renal Failure }\end{array}$ \\
\hline $\begin{array}{l}\text { No. of observations } \\
\text { Mean }( \pm \text { S.D. Level } \\
\text { Median I,evel } \\
>10 \mu \mathrm{g} / \mathrm{ml}\end{array}$ & $\begin{array}{c}172 \\
6 \cdot 68+1 \cdot 42 \\
6 \cdot 8 \\
1 \cdot 7\end{array}$ & $\begin{array}{c}256 \\
7 \cdot 37+2 \cdot 01 \\
7 \cdot 2 \\
8 \cdot 2\end{array}$ & $\begin{array}{c}60 \\
8 \cdot 40 \pm 2 \cdot 73 \\
7 \cdot 4 \\
30 \cdot 0\end{array}$ & $\begin{array}{c}38 \\
8 \cdot 89 \pm 2 \cdot 61 \\
8 \cdot 6 \\
39 \cdot 4\end{array}$ & $\begin{array}{c}58 \\
9 \cdot 98 \pm 3 \cdot 82 \\
9 \cdot 1 \\
34 \cdot 5\end{array}$ & $\begin{array}{c}53 \\
\epsilon \cdot 78 \pm 1.99 \\
6 \cdot 7 \\
7.5\end{array}$ & $\begin{array}{c}11 \\
34 \cdot 54 \pm 24 \cdot 15 \\
30 \cdot 0 \\
90 \cdot 9\end{array}$ \\
\hline
\end{tabular}

*Without hepatic metastases.

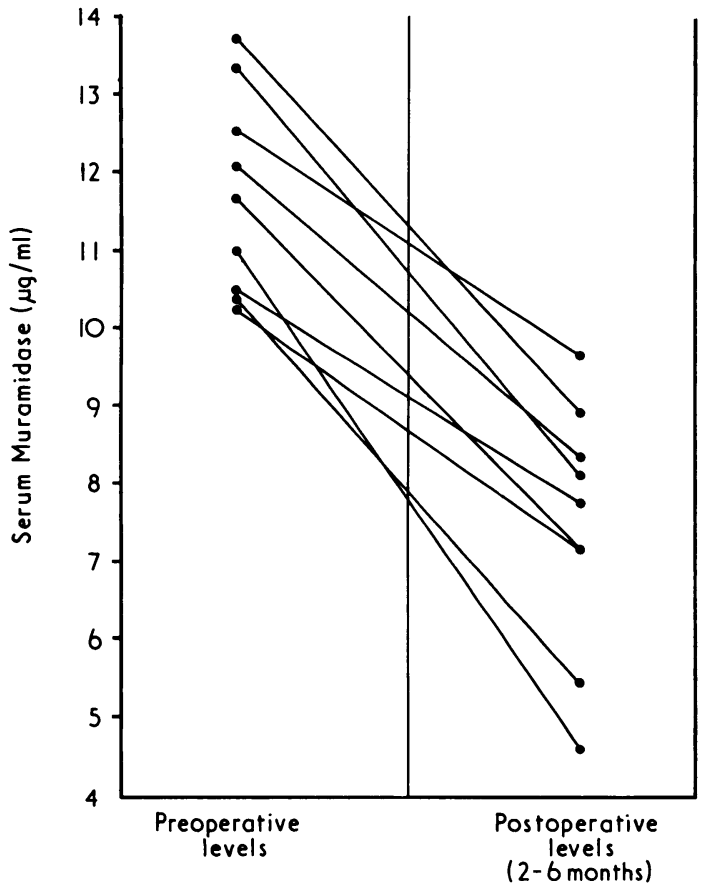
Levels of serum muramidase before and after excision of
tumour in nine patients with primary tumours and raised muramidase levels before operation.

Evidence for coincidental impaired renal function among those patients with raised serum muramidase as judged by serum creatinine levels $(<1.5 \mathrm{mg} / 100 \mathrm{ml})$ was only found in one patient and the muramidase value in this case was double the next highest value of the colorectal group; this patient was excluded from the results.

The two groups of patients who were studied by repeated measurements showed very different patterns of muramidase levels. In the the tumour-free group eight out of $122(6.6 \%)$ observations exceeded $10 \mu \mathrm{g} / \mathrm{ml}$. In the 26 patients with clinically detectable metastases or biochemical patterns suggesting metastases 31 out of $81(38.3 \%)$ levels were greater than $10 \mu \mathrm{g} / \mathrm{ml}$. There was some variation in the occurrence of raised muramidase levels. In some patients it occurred once or twice in a period of several months, in others the level remained high for many months. Out of the 26 patients with metastases 18 had at least one abnormal muramidase value.

Within the tumour-free group the individual variation was small, and patients tended to have levels that remained fairly consistent for that particular person.

There was no correlation between serum creatinine and muramidase levels in 35 patients chosen at random from those with raised muramidase $(r=0.25)$.

Using Student's $t$ test the serum muramidase levels in the following pairs of patient groups were found to be significantly different: postoperative tumour-free patients $v$. controls $(\mathrm{P}<0.001)$, primary-tumour patients $v$. postoperative tumour-free patients $(P<0.001)$, liver-metastases patients $v$. postoperative tumour-free patients $(P<0.001)$, and hepaticmetastases patients $v$. primary-tumour patients $(P<0.001)$.

\section{Discussion}

This study encompassed patients in all phases of colorectal cancer. Though there were statistical differences between the tumour-bearing and tumour-free groups a comparison of the mean and median values for each group showed that, particularly in the case of localized primary tumours, a raised muramidase value in the presence of a tumour was a feature peculiar to certain individuals with the group. When the serum muramidase was raised in a preoperative patient its return to normal after resection of the tumour strongly suggested a relation between the raised enzyme activity and the presence of the tumour.

In this study we were using the C.E.A. as an early indicator of recurrence or metastases. A raised serum muramidase was more frequent in patients with abnormal C.E.A. levels than when the C.E.A. was normal. On the other hand, there was no statistical correlation between the muramidase activity in serum and the plasma C.E.A. level in the tumourbearing group of patients as a whole.

Though it is well established that muramidase is filtered by the glomeruli and reabsorbed by the tubules there was no evidence that a defect of this mechanism, as indicated by a raised creatinine, is the cause of a raised blood muramidase in cancer. Likewise in patients with hepatic metastases it is unlikely that an effect of the tumour cells upon the hepatic parenchymal cell function leads to an increase of muramidase production. This is supported by the low frequency of abnormal muramidase levels in various types of benign liver disease investigated in this series and by a previous report that an increased muramidase in the blood occurred in only $6 \%$ of patients with acute viral hepatitis. (Hendrick et al., 1969).

At present the reason why some patients with cancer show a raised muramidase activity is still a matter of conjecture. It is tempting to suggest that it is a reflection of a host-tumour reaction. Some supporting evidence can be cited. Barrett (1970) found that $62 \%$ of 100 patients with various cancers had an absolute monocyte count of over $500 / \mathrm{mm}^{3}$ and $21 \%$ a count greater than $1,000 / \mathrm{mm}^{3}$, the normal being $335 \pm 153$ / $\mathrm{mm}^{3}$ (mean $\pm \mathrm{SD}$ ). Monocytosis of above $500 / \mathrm{mm}^{3}$ has been reported in $30 \%$ of 220 cases of pancreatic carcinoma (Moldow, 1971). More recently, Gordon et al. (1974) observed that activated mononuclear phagocytes in vitro produce substantially more muramidase than unstimulated macrophages. This focuses attention on the possibility of an alteration of the production of muramidase in some cancer patients by the granulocyte-monocyte-macrophage system. The independence of the serum muramidase level in relation to the tumour mass or the type of tumour (Fogelson and Lobstein, 1954) would fit this hypothesis. In view of the postoperative fall of muramidase in those patients with preoperative raised level it is interesting to note that comparable changes have been reported in experimental animals. Perri et al. (1963) found increased muramidase activity in the kidney and spleen of rats bearing Jensen sarcomas, and excision of the tumours resulted in the enzyme activity returning to normal. At that time these authors suggested it.was a reflection of a stimulation of the reticuloendothelial system. This explanation would seem to be applicable to man. The reason why only some 
cancer bearing patients show this change is unknown. Repeated observations on patients at risk of developing metastases or recurrence, however, indicate that transient rises of serum muramidase are not an uncommon feature in this group of patients. Only time will tell if such rises have any real prognostic significance.

We thank Professor M. S. Losowsky, Dr. F. M. Parsons, Mr. A. MacAdam, and Mr. R. Hall for allowing us to investigate their patients. This study was supported by the Yorkshire Cancer Research Campaign.

\section{References}

Barrett, O. N. (1970). Annals of Internal Medicine, 73, 991.

Egan, M. L., et al. (1972). Immunochemistry, 9, 289.
Fink, M. E., and Finch, S. C. (1968). Proceedings of the Society for Experimental Biology and Medicine, 127, 365.

Fogelson, S. J., and Lobstein, O. E. (1954). American fournal of Digestive Diseases, 21, 324.

Gordon, S., Todd, J., and Cohn, Z. A. (1974). Fournal of Experimental Medicine, 139, 1228.

Hayslett, J. P., Perillie, P. E., and Finch, S. C. (1968). New England fournal of Medicine, 279, 506 .

Hendrick, F., et al. (1969). Wiener klinische Wochenschrift, 119, 231.

Kovanyi, G., and Letnansky, K. (1971). European fournal of Cancer, 7, 25.

Levi, J. A., MacQueen, A., and Vincent, P. C. (1973). British fournal of Haematology, 25, 757.

Moldow, R. E. (1971). Annals of Internal Medicine, 74, 449.

Pascual, R. S., Gee, J. B. L., and Finch, S. C. (1973). New England Fournal of Medicine, 289, 1074 .

Perillie, P. E., and Finch, S. C. (1973). Medical Clinics of North America, $57,395$.

Perillie, P. E., Khan, K., and Finch, S. C. (1973). American Fournal of the Medical Sciences, 265, 297.

Perri, G. G., et al. (1963). Cancer Research, 23, 431.

Prockop, D. J., and Davidson, W. D. (1964). New England fournal of Medicine, 270, 269.

Rogoway, W. M., and Finch, S. C. (1963). Clinical Research, 11, 198.

Steele, L., et al. (1974). British fournal of Cancer. In press.

\section{MEDICAL MEMORANDA}

\section{Case of Glomerulonephritis associated with Acute Toxoplasmosis}

\author{
it 2 \\ B. E. GINSBURG, J. WASSERMAN, GUNNEL \\ HULDT, A. BERGSTRAND
}

British Medical fournal, 1974, 3, 664-665

Experimental studies on mice and rabbits have shown that toxoplasmosis can be accompanied by immune-complex nephritis (Huldt, 1970, 1971). A case has also appeared in which the nephrotic syndrome was diagnosed in an infant with congenital toxoplasmosis (Wickbom and Winberg, 1972). In view of these reports an investigation was begun for the detection of toxoplasma antigen in renal biopsy specimens. During 1971-2, 150 such specimens taken consecutively were tested by immunofluorescence for reactivity with an anti-toxoplasma conjugate.

We report here a case found during that study. The patient, a child, had immune-complex disease including glomerulonephritis. Material stainable with anti-toxoplasma conjugate was found in the glomeruli and a rise in circulating anti-toxoplasma antibodies was shown.

\section{Case Report}

An 8-year-old boy was admitted to hospital acutely ill with abdominal pain, pain in the joints, and fever $\left(38 \cdot 2^{\circ} \mathrm{C}\right)$. He had a maculopapular rash on the neck and arthralgia. Palpation of the lymph nodes showed no striking enlargement. Urine contained a trace of protein. Blood pressure was $140 / 100 \mathrm{~mm} \mathrm{Hg}$.

\section{Paediatric Department, St. Göran's Hospital, Stockholm}

B. E. GINSBURG, M.D. Stockholm County Council Central Microbiological Laboratory,
Stockholm

J. WASSERMAN, M.D., Head of Department

National Bacteriological Laboratory, Stockholm

GINNEL HULDT, M.D., Head of Department Department of Pathology, Karolinska Institute, Sabbatsberg
Hospital, Stockholm

A. BERGSTRAND, M.D., Assistant Professor
During the first weeks he was somnolent and had increasing muscular tenderness. There was a granulocytosis $\left(16,200 / \mathrm{mm}^{3}\right)$, a slight monocytosis $\left(900 / \mathrm{mm}^{3}\right)$, and a marked increase in platelets $\left(712,000 / \mathrm{mm}^{3}\right)$. Muscle enzymes (serum creatinkinase and aldolase) were raised, but total lactate dehydrogenase was normal. Electromyography showed a myositis pattern. Renal biopsy findings were compatible with an immune-complex nephritis.

The presence of toxoplasma antigen in the glomeruli led to a serological examination for antibodies to toxoplasma (see table). The mother gave a negative dye test result. The dye tests were performed according to the method of Sabin and Feldman (1948) as modified by Huldt (1958). Whole serum was tested by immunofluorescence using class-specific conjugates as described previously (Huldt et al., 1973).

Reciprocal Antibody Titres

\begin{tabular}{cc|c|c|c|c}
\hline \multicolumn{2}{c|}{ Date } & Dye Test & IgM & IgA & IgG \\
\hline $7 / 2 / 72$ & $\cdots$ & 50 & 20 & Neg. & 80 \\
$11 / 2 / 72$ & $\cdots$ & 250 & 5 & 10 & 80 \\
$14 / 2 / 72$ & $\cdots$ & 1,250 & 5 & 10 & 80 \\
$16 / 2 / 72$ & $\cdots$ & 1,250 & 5 & 10 & 160 \\
$11 / 4 / 72$ & $\cdots$ & 50 & Neg. & Neg. & 40 \\
$24 / 4 / 72$ & $\cdots$ & 50 & Neg. & Neg. & 20 \\
$17 / 5 / 73$ & $\cdots$ & 50 & Neg. & Neg. & 20 \\
\hline
\end{tabular}

Titres were obtained by simultaneous testing of all sera.

The following conjugates were used: sheep antihuman IgM, Wellcome batch K 2142; sheep antihuman IgA, Wellcome batch $\mathrm{K} 5777$; and sheep antihuman IgG, Wellcome batch $100^{11} \mathrm{~A}$. Specificity tests for the conjugates were performed according to Bergquist and Kreisler's (1974) method. Toxoplasma was not isolated from samples of heparinized blood and urine taken on days 15 and 22 .

Over the next few months the patient's condition deteriorated. He developed oedema, gross haematuria, an increase in proteinuria to $7 \cdot 2 \mathrm{~g} / \mathrm{l}$., and glucosuria. Haemoglobin was $7.7 \mathrm{~g} / 100 \mathrm{ml}$, blood urea nitrogen $\cdot 44.6 \mathrm{mg} / 100 \mathrm{ml}$, and serum cholesterol $642 \mathrm{mg} / 100 \mathrm{ml}$. Antistreptolysin titre was $400 \mathrm{IU} / \mathrm{ml}$. Antinuclear antibodies were not detected.

Prednisolone $0.5 \mathrm{mg} / \mathrm{kg}$ was given daily for five months. Pyrimethamine and sulphafurazole were given for six weeks starting on day 16. After five months a gradual improvement was seen and after 10 months there were no clinical symptoms.

Two further renal biopsies were performed 5 and 17 months after. the onset of the disease.

\section{LIGHT MICROSCOPY}

First Biopsy (fig. 1)-The glomeruli were large with increased cellularity and swelling of endothelial and mesangial cells. The narrow, 